[Agr. Biol. Chem., Vol. 31, No. 1, p. 48 53, 1967]

\title{
Studies on the Amino Acid Sequence of Holmes Rib-Grass Strain Virus Protein
}

\author{
Part I. Separation of $\mathrm{pH} 4.5$ Soluble Tryptic Peptides and \\ Amino Acid Sequences of Some Small Peptides \\ of Holmes Rib-Grass Strain Virus Protein
}

\author{
By Gunki Funatsu and Masaru Funatsu \\ Laboratory of Biochemistry, Faculty of Agriculture, \\ Kyushu University, Fukuoka, Japan \\ Received July 11, 1966
}

\begin{abstract}
The $\mathrm{pH} 4.5$ soluble tryptic peptides of Holmes Rib-Grass strain virus protein were fractionated by Dowex $1 \times 2$ column chromatography and their amino acid compositions were determined. The purification of the peptides has been achieved by chromatography on Dowex $-1 \times 2$ following paper chromatography. The sequences of five small peptides have been established. These are as follows. T-3; Asn-Arg, T-5; Asp-Thr-Val-Arg, T-6; Ser-Phe-Asp-Thr-Arg, T-7; Phe-Pro-Asp-Thr-Gly-Phe-Arg, T-9; Val-Asp-Asp-Ala-Thr-ValAla-lleu-Arg.
\end{abstract}

Holmes Rib-Grass (HR) strain virus originally isolated from rib grass by Holmes" produces distinctive necrotic ring patterns on Turkish tobacco and local lesions on $N$. sylvestris, and has been considered as a natural mutant strain of tobacco mosaic virus (TMV). Total number of amino acid residues in this HR-protein, 158, has been determined to be equivalent to that of TMV-protein. ${ }^{2 \prime}$

In the previous papers, ${ }^{2,31}$ however, it was shown that the peptides obtained by tryptic digestion as well as the amino acid composition of the HR-protein were fairly different from those of TMV-protein.

In this paper, the separation of the digest of HR-protein with trypsin from Sigma Corp. on Dowex $1 \times 2$ column and the sequences of amino acids in certain small peptides are reported.

1) F. O. Holmes, Phytopathology, 31, 1089 (1941).

2) A. Tsugita, J. Mol. Biol., 5, 293 (1962).

3) G. Funatsu, Biochemistry, 3, 1351 (1964).

\section{EXPERIMENTALS}

The virus protein was isolated by the acetic acid method.4) Two times crystallized trypsin was purchased from the Sigma Corp., and chymotrypsin from Worthington Biochemical Corp. was used for digestion of peptide.

Digestion of protein. The protein was digested with $1 \%$ of trypsin at $37^{\circ} \mathrm{C}$ for two hours using an autotitrator to maintain the $\mathrm{pH}$ at 8.0 . During digestion, a precipitate like gel was produced. The reaction mixture was adjusted to $\mathrm{pH} 4.5$ with $1 \mathrm{~N}$ acetic acid and allowed to stand for thirty minutes in an ice bath. The precipitate was suspended in water at $\mathrm{pH} 8.5$ and again adjusted to $\mathrm{pH} 4.5$ with $1 \mathrm{~N}$ acetic acid. This procedure was repeated twice. The resulting supernatants were combined and 1 yophilized.

Chromatography on Dowex $1 \times 2$ column. The mixture of $\mathrm{pH} 4.5$ soluble peptides was dissolved in a small amount of a pyridine-acetic acid buffer, $\mathrm{pH}$ 8.5 (2\% pyridine solution was adjusted to $\mathrm{pH} 8.5$ with concentrated acetic acid), and applied to a Dowex $1 \times 2(200 \sim 400 \mathrm{mesh}$; acetate form) column

4) H. Fraenkel-Conrat, Virology, 4, 1 (1957). 
Table I. Amino Acid Compositions of Tryptic Peptides of HR-protein

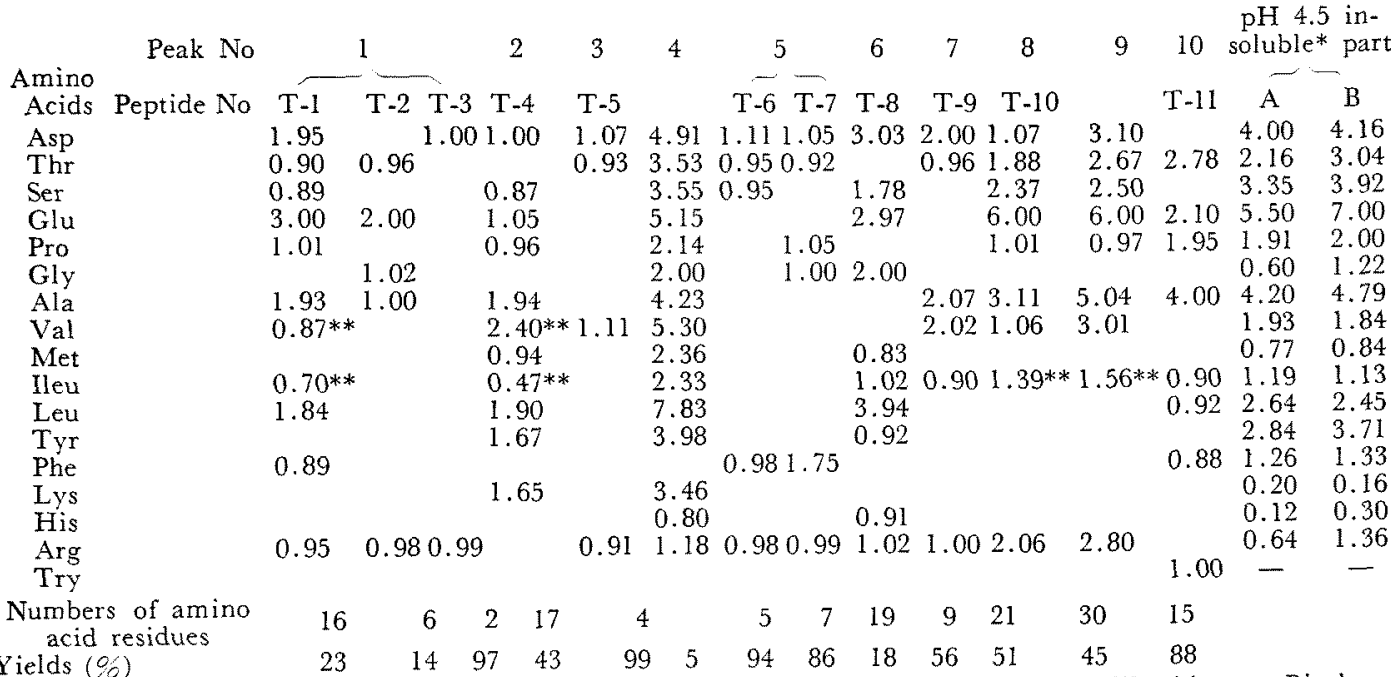

* $\mathrm{A}$ and $\mathrm{B}$ were the insoluble parts obtained by digestion with trypsins from Worthington Biochem. Corp. and Sigma Corp., respectively.

* Ileu-lleu and Ileu-Val bonds are not split completely by 24 hours hydrolysis.

$(1.1 \times 50 \mathrm{~cm})$ which had been equilibrated with above pyridine-acetic acid buffer, $\mathrm{pH}$ 8.5. The column was developed successively by a linear gradient system at room temperature with following buffers: $\mathrm{pH} 8.5$, $2 \%$ pyridine-acetic acid buffer; $\mathrm{pH} 7,2 \%$ pyridineacetic acid buffer; $0.01 \mathrm{~N}$ acetic acid; $0.02 \mathrm{~N}$ acetic acid; $0.1 \mathrm{~N}$ acetic acid; $1 \mathrm{~N}$ acetic acid and $30 \%$ acetic acid. Analyses of the peptides in each fraction were carried out by Folin-Lowry method as described previously, ${ }^{3}$ )

Paper chromatography. Further purification of peptides was performed by descending paper chromatography using $n$-BuOH-AcOH-H $\mathrm{H}_{2}-\mathrm{O}$-pyridine $(30: 6$ : $24: 20$ ). After development, the peptide was detected by ninhydrin $(0.2 \%)$ in acetone, the hypochlorite starch-KI test ${ }^{5}$ and Sakaguchi test $\left.{ }^{6}\right)$, and then eluted with $1 \%$ ammonia solution or $0.2 \mathrm{~N}$ acetic acid.

Amino acid analyses. Peptides were hydrolyzed in evacuated and sealed tubes with constant boiling hydrochloric acid at $108^{\circ} \mathrm{C}$ for twenty-four hours. The analyses were performed with the automatic recording equipment of Spackman et al. ${ }^{7}$

5) S. C. Pan and J. D. Dutcher, Anal. Chem., 38, 836 (1956).

6) J. B. Jepson and I. Smith, Nature, 172, 1100 (1953).

7) D. H. Spackman, W. H. Stein, and S. Moore, Anal. Chem., 30, 1190 (1958).
Digestion of peptides with chymotrypsin. Peptide was dissolved in $1 \% \%$ of ammonium acetate solution and adjusted to $\mathrm{pH} 8$ with ammonium hydroxide, and then digested with $2 \%$ of chymotrypsin at $37^{\circ} \mathrm{C}$ for two hours. After drying and redissolving in pyridine-collidine-acetic acid buffer $(40,40$, and $0.3 \mathrm{ml}$, respectively, in $4000 \mathrm{ml}$.), $\mathrm{pH} 8.6$, the solution was applied to a Dowex $1 \times 2$ column $(0.9 \times 60 \mathrm{~cm})$ equilibrated with pyridine-collidine-acetic acid buffer, pH 8.6, and eluted at room temperature with the same buffer system as described in the structural analysis of peptide 10 of TMV-protein by means of a ninechamber Autograd with a total volume of $70 \mathrm{ml}$. per chamber. ${ }^{8}$ )

Edman degradation. The Edman degradation as modified by Konigsberg and Hill's) was used in the substractive method in which the stepwise degradation was followed by amino acid analysis of the residual peptides without purification by a Dowex $50 \times 2$ column after cyclization.

\section{RESULTS AND DISCUSSION}

The separation of $\mathrm{pH} 4.5$ soluble tryptic peptides from HR-protein has been achieved

8) G. Funatsu, A. Tsugita, and H. Fraenkel-Conrat, Arch. Biochem. Biophys., 105, 25 (1964).

9) W. Konigsberg, and R. J. Hill, J. Biol. Chem., 237, 2547 (1962). 


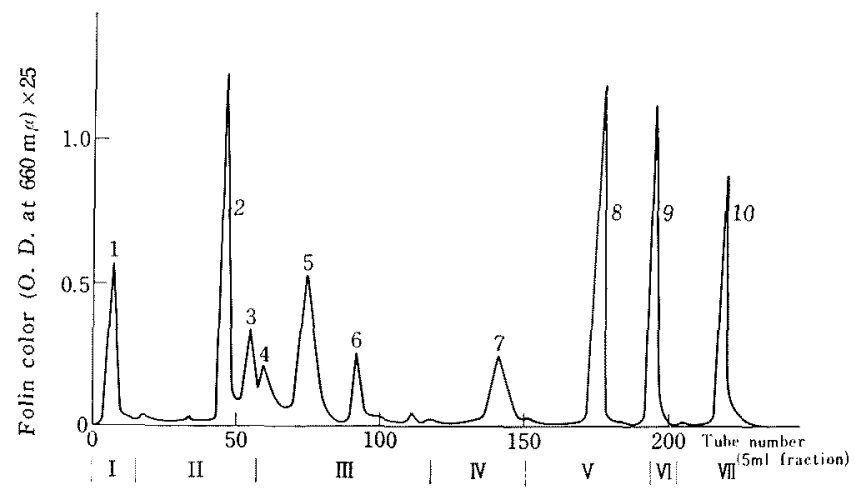

FIG. 1. Chromatography of Tryptic Digest of HR-Protein on Dowex $1 \times 2$ Column $(1.1 \times 50 \mathrm{~cm})$.

Tryptic digest of HR-protein was applied to the Dowex $1 \times 2$ which was equilibrated with $2 \%$ pyridine-AcOH buffer $(\mathrm{pH} 8.5$ ) and then eluted by following buffer system. Flow rate, 12 tubes per hr. I; $2 \%$ pyridine-AcOH buffer ( $\mathrm{pH} 8.5$ ), II. $2 \%$ pyridine- $\mathrm{AcOH}(\mathrm{pH}$ 7) $100 \mathrm{ml} \stackrel{\text { gradient }}{\rightarrow} 0.01 \mathrm{~N}$ AcOH $100 \mathrm{ml}$, III. $0.01 \mathrm{~N} \mathrm{ACOH} 150 \mathrm{ml} \stackrel{\text { gradient }}{\rightarrow} 0.02 \mathrm{~N}$ AcOH $150 \mathrm{ml}$, IV. $0.02 \mathrm{~N}$ $\mathrm{AcOH}, \mathrm{V} .0 .02 \mathrm{~N}$ AcOH $150 \mathrm{ml} \stackrel{\text { gradient }}{\rightarrow} 0.1 \mathrm{~N} \mathrm{AcOH} 150 \mathrm{ml}$, VI. $1 \mathrm{~N} \mathrm{AcOH}$, VII, $1 \mathrm{~N} \mathrm{AcOH} 100 \mathrm{ml} \stackrel{\text { gradient }}{\longrightarrow} 30 \%$ AcOH $100 \mathrm{ml}$.

by Dowex $1 \times 2$ column chromatography using a nine-chamber Autograd as described previously, ${ }^{3 \prime}$ but chromatography on Dowex $1 \times 2$ column $(1.1 \times 50 \mathrm{~cm})$ by stepwise elution system was also used to separate these peptides, as seen in Fig. 1. The chromatographic pattern was almost the same as that obtained in the previous experiment $t^{31}$ except a poor separation of the basic and neutral peptides and better separation of acidic peptides. In some cases, the peptides in each fraction were purified by paper chromatpgraphy at need (Fig. 2). Amino acid composition of each purified peptide was summarized in Table I.

Peak 1. Three peptides, T-1, T-2, and T-3, were included in this peak. T-1 was insoluble upon elution and separated from $\mathrm{T}-2$ and $\mathrm{T}-3$. Low yield of T-1 may be due to its insolubility. The behaviour on column chromatography infers that these three peptides were basic and glutamic and aspartic acid residues would be amide form. T-1 could be separated from

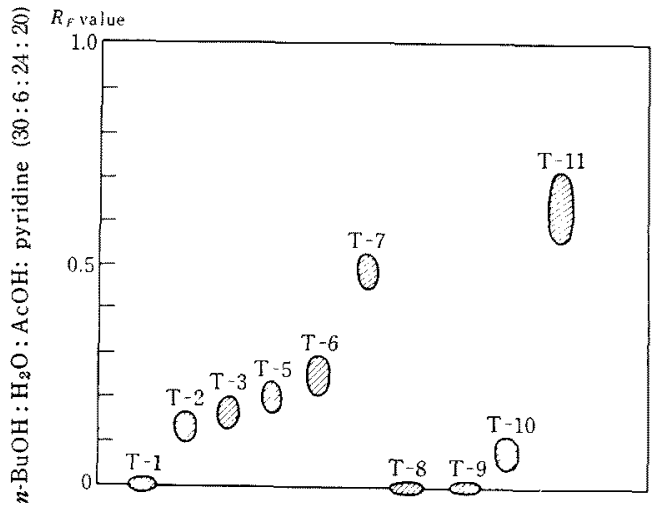

FIG. 2. Descending Paper Chromatogram of Each Tryptic Peptide Using n-BuOH-AcOH-WaterPyridine $(30: 6: 24: 20)$ as Solvent System.

the others, but the separation of $\mathrm{T}-2$ from T-3 was not achieved by paper chromatography.

When the $\mathrm{pH}$ of the buffer employed for equilibration and elution on column chromatography was higher (for example 8.8), T-3 was 
eluted after T-1 and T-2 and obtained in pure form. Since T-3 was basic peptide and its N-terminal amino acid was found to be Asp by Edman degradation method, the structure of T-3 was Asn-Arg which corresponds to peptide 7 of TMV-protein.

The yield of T-2 was about $50 \%$ when twice crystallized trypsin from Worthington Biochem. Corp. was employed, while the digestion with Sigma-trypsin gave only $14 \%$. Though $\mathrm{pH}$ 4.5 insoluble part was not yet pure, its amino acid composition gave apparently less content of Thr, Glu, Ala, Gly, and Arg in that obtained by digestion with former trypsin as shown in Table I. These results suggested that T-2 might be derived from $\mathrm{pH} 4.5$ insoluble peptide (possibly large $\mathrm{N}$-terminal peptide) as a result of the action of chymotrypsin contaminated in the trypsin preparation employed and would not be tryptic peptide. Edman degradation of this peptide gave the structure of Gln-Thr-Gln-Ala-GlyArg.

Peak 2. Two lysine residues in the HRprotein were contained in this $\mathrm{T}-4$ peptide. Since this peptide was not further digested by trypsin, one of these lysine residues may locate at $\mathrm{N}$-terminus of proline residue. This peptide was partially precipitated at $\mathrm{pH} 4.5$.

Peak 3. This peak included T-5. The amino acid composition of this peptide was $\mathrm{Asp}_{1}, \mathrm{Thr}_{1}, \mathrm{Val}_{1}, \mathrm{Arg}_{\mathrm{l}}$ even after hydrolysis for seventy-two hours, in contradictory to the result obtained by Tsugita ${ }^{2)}\left(\mathrm{Asp}_{1}, \mathrm{Thr}_{1}, \mathrm{Val}_{2}\right.$, $\left.A r g_{1}\right)$. The sequence of $T-5$ was determined by Edman degradation.

On step 3, the amount of all other amino acids was less than that of arginine. Since

$\begin{array}{rcccc}\text { T-5: } & \text { Asp } & \text { Thr } & \text { Val } & \text { Arg } \\ & 1.00 & 0.87 & 1.04 & 0.95 \\ \text { Step 1 (100\%) } & 0.18 & 0.87 & 1.04 & 0.94 \\ \text { Step 2(100\%) } & 0.04 & 0.08 & 1.04 & 0.92\end{array}$

this peptide behaved as neutral one on column chromatography, $\beta$-carboxyl residue of aspartic acid should be free. From these results, the sequence of T-5 was estimated as Asp-ThrVal-Arg.

Peak 4. Histidine and lysine were detected in this fraction. From amino acid analysis, it was concluded that the peak was a mixture of two peptides consisted of very similar amino acid residues to both $\mathrm{T}-4$ and $\mathrm{T}-8$. The yields were very low and a further study on these peptides has not yet been done.

Peak 5. Peptides T-6 and T-7, separated previously by a long column, ${ }^{3)}$ were eluted together in this peak. These peptides were separated upon paper chromatography. Edman degradation was applied to these peptides.

$\begin{array}{ccccccc}\text { T-6: } & \text { Ser } & \text { Phe } & \text { Asp } & \text { Thr } & \text { Arg } \\ & 1.00 & 0.93 & 1.05 & 0.90 & 0.96 \\ \text { Step 1 }(92 \%) & 0.00 & 0.93 & 1.05 & 0.93 & 0.99 \\ \text { Step 2 }(97 \%) & 0.00 & 0.11 & 1.05 & 0.93 & 0.98 \\ \text { Step 3 }(63 \%) & 0.00 & 0.00 & 0.17 & 0.93 & 0.98 \\ \text { T-7: } & \text { Phe } & \text { Pro } & \text { Asp } & \text { Thr } & \text { Gly } & \text { Arg } \\ & 1.77 & 0.97 & 1.00 & 0.92 & 1.00 & 1.01 \\ \text { Step 1 (80\%) } & 0.90 & 0.98 & 1.00 & 0.93 & 1.00 & 0.99 \\ \text { Step 2 (86\%) } & 0.89 & 0.02 & 1.01 & 0.92 & 1.00 & 1.02 \\ \text { Step 3 }(93 \%) & 0.91 & 0.01 & 0.37 & 0.91 & 1.00 & 1.02 \\ \text { Step 4 (100\%) } & 0.91 & 0.01 & 0.12 & 0.28 & 1.00 & 1.01 \\ \text { Step 5 }(74 \%) & 0.90 & 0.01 & 0.09 & 0.12 & 0.52 & 0.98\end{array}$

Both peptide were neutral on behavior in column chromatography. From these results, the sequences of T-6 and T-7 were Ser-PheAsp-Thr-Arg and Phe-Pro-Asp-Thr-Gly-PheArg, respectively. T-7 could correspond to the peptide 4 from TMV-protein which has a lysine at C-terminus.

Peak 6. A pure peptide, T-8, which contained histidine was found in this peak. The low yield of this peptide may be due to its partial insolubility, because some of histidine was detected in $\mathrm{pH} 4.5$ insoluble part as shown in Table I. This peptide was precipitated from the eluate and showed similar properties to the peptide 10 of TMV-protein.

Peak 7. Peptide T-9 was accompanied with a very small amount of peptide containing methionine. This peptide was purified by a paper chromatography. Since this peptide was acidic on behavior in column chromato- 
graphy, $\beta$-carboxyl groups of both aspartic acid residues should be free. After digestion with chymotrypsin, the peptide was separated into two fragments, T-9 Chy-1 and T-9 Chy-2, on Dowex $1 \times 2$ column (Fig. 3). Amino acid

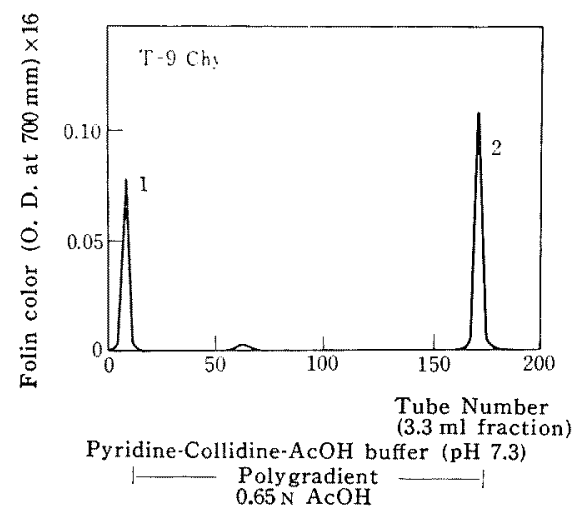

FJG. 3. Chromatography of Chymotryptic Digest of Peptide T-9 on Dowex $1 \times 2$ Column $(0.9 \times$ $60 \mathrm{~cm}$ ).

Chymotryptic digest of peptide T-9 was applied to the Dowex $1 \times 2$ column which was equilibrated with pyridine-collidine-AcOH (pH 8.6) and the eluted by means of a polygradient system having pyridine-collidine-AcOH buffer ( $\mathrm{pH} 7.3$ ). $0.02 \mathrm{~N} \mathrm{AcOH}$, $0.2 \mathrm{~N} \mathrm{AcOH}, 0.35 \mathrm{~N} \mathrm{AcOH}, 0.5 \mathrm{~N} \mathrm{AcOH}$, and $0.65 \mathrm{~N}$ AcOH. Flow rate, 12 tubes per hr.

compositions of both fragment were $\mathrm{Ala}_{1,00}$, $\mathrm{Val}_{0.97}, \mathrm{Ileu}_{0.87}, \mathrm{Arg}_{0.98}$ and $\mathrm{Asp}_{2.00}, \mathrm{Thr}_{0.88}$, $\mathrm{Ala}_{0.95}, \mathrm{Val}_{1.01}$, respectively. These were subjected to the Edman degradation, obtaining the following results.

$\begin{array}{rllll}\text { T-9 Chy-1: } & \text { Val } & \text { Ala } & \text { Ileu } & \text { Arg } \\ & 0.97 & 1.00 & 0.87 & 0.98 \\ \text { Step 1 (97\%) } & 0.00 & 1.00 & 0.91 & 0.98 \\ \text { Step 2 (52\%) } & 0.00 & 0.00 & 1.00 & 1.03\end{array}$

Therefore, the sequence of T-9 Chy-1 was Val-Ala-Ileu-Arg. The sequence of T-9 Chy-2

$\begin{array}{rllll}\text { T-9 Chy-2: } & \text { Val } & \text { Asp } & \text { Ala } & \text { Thr } \\ & 1.01 & 2.00 & 0.95 & 0.88 \\ \text { Step I (76\%) } & 0.00 & 2.00 & 0.95 & 0.86 \\ \text { Step 2 (70\%) } & 0.00 & 1.10 & 1.00 & 0.96 \\ \text { Step 3 (59\%) } & 0.00 & 0.31 & 1.00 & 0.96 \\ \text { Step 4(56\%) } & 0.00 & 0.28 & 0.30 & 1.00\end{array}$

was established to be Val-Asp-Asp-Ala-Thr. Thus, the sequence of T-9 was concluded to be Val-Asp-Asp-Ala-Thr-Val-Ala-Ileu-Arg, which was completely the same as the peptide 9 of TMV-protein.

Peak 8. A pure peptide T-10 was obtained from this peak. Two arginine residues were found in this peptide, in contradictory to the data reported previously. ${ }^{31} \mathrm{~N}$-Terminal amino acid was Ileu.

Peak 9. The peptide eluted in this place was an incomplete digest of the peptide T-9 and $\mathrm{T}-10$ as described previously. ${ }^{31}$

Peak. 10. C-Terminal peptide T-11 was obtained in pure form. When trypsin having higher chymotryptic activity was employed for digestion, this peptide was splitted into two fragments. One of them has amino acid composition of $\mathrm{Thr}_{2.68}, \mathrm{Pro}_{0.98}, \mathrm{Ala}_{2.10}$, which was eluted near $\mathrm{T}-4$, and the other consisting of $\mathrm{Glu}_{2.00}, \mathrm{Pro}_{1.08}, \mathrm{Ala}_{1.90}, \mathrm{Ileu}_{0.81}, \mathrm{Leu}_{0.95}$, $\mathrm{Phe}_{0.89}$ Try $_{1.0}$ was eluted after T-11.

pH 4.5 insoluble peptide. As can be seen in Table I, the amino acid composition of this fraction was not clear. There was a possibility that a main peptide was contaminated with some other peptides, especially T-4 containing two lysine and T-8 containing histidine, in contrary to the case of TMV A chromatography on ion-exchange cellulose also failed to purify this main peptide. Therefore, further purification by other method was required.

Comparing the tryptic peptides with those reported by Tsugita, ${ }^{2)}$ there are many differences in their amino acid compositions. Especially the peptides corresponding to $\mathrm{T}-7$ and $T-8$ were not found in his peptides. Total number of amino acids accounted for the isolated soluble peptides was 115 and the remaining number of amino acids was calculated to be 43 . This suggested that all tryptic peptides would be isolated, except a large N-terminal peptide, which requires a further purification.

Acknowledgment A part of this work was done at Virus Laboratory, University of 
California, U.S. A. The authors are indebt- authors wish to express thanks to Mrs. M. ed to Dr. H. Fraenkel-Conrat for encourage- Stanley, Miss. L. Easton, and Miss S. Goto ment and discussion, and Dr. C. A. Knight for devoted technical assistance. for a supply of mutant protein. Also the 